This is the final peer-reviewed accepted manuscript of:

BRUNO, LUIGI; AMOROSI, ALESSANDRO; Severi, Paolo; COSTAGLI, BIANCA: Late Quaternary aggradation rates and stratigraphic architecture of the southern Po Plain, Italy. BASIN RESEARCH 29. 0950-091X

DOI: $10.1111 /$ bre.12174

The final published version is available online at: $\mathrm{http}: / / \mathrm{dx}$. doi.org/10.1111/bre.12174

Rights / License:

The terms and conditions for the reuse of this version of the manuscript are specified in the publishing policy. For all terms of use and more information see the publisher's website.

This item was downloaded from IRIS Università di Bologna (https://cris.unibo.it/)

When citing, please refer to the published version. 


\title{
Late Quaternary aggradation rates and stratigraphic architecture of the southern Po Plain, Italy
}

\author{
Luigi Bruno,* Alessandro Amorosi,* Paolo Severi† and Bianca Costagli* \\ *Department of Biology, Earth and Environmental Sciences, University of Bologna, Bologna, Italy \\ $\dagger$ Geological, Seismic and Soil Survey, Regione Emilia-Romagna, Bologna, Italy
}

\begin{abstract}
The Po River Basin, where accumulation and preservation of thick sedimentary packages are enhanced by high rates of tectonic subsidence, represents an ideal site to assess the relations between vertical changes in stratigraphic architecture and sediment accumulation rates. Based on a large stratigraphic database, a markedly contrasting stratigraphy of Late Pleistocene and Holocene deposits is reconstructed from the subsurface of the modern alluvial and coastal plains. Laterally extensive fluvial channel bodies and related pedogenically modified muds of latest Pleistocene age are uncon formably overlain by Holocene overbank fines, grading seaward into paralic and nearshore facies associations. In the interfluvial areas, a stiff paleosol, dating at about 12.5-10 cal ky BP, marks the Pleistocene-Holocene boundary. Across this paleosol, aggradation rates (ARs) from 16 radiocarbon dated cores invariably show a sharp increase, from $0.1-0.9 \mathrm{~mm}$ year ${ }^{1}$ to $0.9-2.9 \mathrm{~mm}$ year ${ }^{1}$. Com paratively lower Pleistocene values are inferred to reflect fluvial activity under a low accommodation (lowstand and early transgressive) regime, whereas higher ARs during the Holocene are related to increasing accommodation under late transgressive and highstand conditions. Holocene sediment accumulation patterns vary significantly from site to site, and do not exhibit common trends. Very high accumulation rates $\left(20-60 \mathrm{~mm}\right.$ year ${ }^{1}$ ) are indicated by fluvial channel or progradational delta facies, suggesting that extremely variable spatial distribution of Holocene ARs was primarily con trolled by autogenic processes, such as fluvial channel avulsion or delta lobe switching. Contrasting AR between uppermost Pleistocene and Holocene deposits also are reported from the interfluves of several coeval, alluvial coastal plain systems worldwide, suggesting a key control by allogenic pro cesses. Sediment accumulation curves from adjacent incised valley fills show, instead, variable shapes as a function of the complex mechanisms of valley formation and filling.
\end{abstract}

\section{INTRODUCTION}

The contrast between Late Pleistocene and Holocene facies architecture is a basic motif of the late Quaternary stratigraphy of several coastal and alluvial systems world wide (Amos \& Knoll, 1987; Blum \& Törnqvist, 2000; Blum \& Aslan, 2006). Late Pleistocene (glacial) deposits differ substantially from their Holocene (interglacial) counterparts in a batch of parameters including facies distribution and mode of sediment accumulation and preservation (Allen \& Posamentier, 1993; Hori et al., 2002; Sarkar et al., 2009; Tanabe et al., 2013; Dung et al., 2014; Yoo et al., 2014). Although these parameters may vary in distinct ways, as a function of tectonic setting (Posamentier et al., 1988) and regional position within the basin (Zaitlin et al., 1994), the Late Pleistocene/ Holocene dichotomy remains a widely recognized trait.

Studies from fluvial systems along the Gulf of Mexico coastal plain (Autin et al., 1991; Blum \& Valastro, 1994;

Correspondence: Luigi Bruno, Department of Biology, Earth and Environmental Sciences, University of Bologna, Via Zam boni, 67, 40126 Bologna, Italy. E mail: luigi.bruno4@unibo.it
Blum et al., 1994; Blum \& Aslan, 2006) and from northern Europe (Busschers et al., 2005; Vis \& Kasse, 2009) outline the stratigraphic architecture of Late Pleistocene paleovalleys, developed during Marine Isotope Stages (MISs) 4 to 2, as composed of: (i) basal, amalgamated channel fills (see Blum et al., 2013; for a review), which result from degradation, lateral migration and subordinate aggradation during sea level fall and subsequent low stand; and (ii) upper, nonamalgamated valley fills, reflecting multiple episodes of aggradation during sea level rise and highstand. Adjacent to the paleovalley systems, large interfluvial sectors remained unfed and subaerially exposed for thousands of years, giving rise to extensive soil development (Van Wagoner et al., 1990). Sedimentation started again in these areas during the Holocene, after complete valley filling.

In subsiding basins, where depositional architecture records prolonged phases of net aggradation punctuated by shorter periods of fluvial incision and/or lateral migration of channels, the late Quaternary stratigraphy exhibits a similar glacial/interglacial bipartition (Chen et al., 2004; Choi \& Kim, 2006), with higher preservation of 
forced regressive and lowstand deposits (Blum \& Törn qvist, 2000). At these locations, the Late Pleistocene stratigraphy consists of aggradationally stacked, amalgamated channel belt sand bodies (Blum et al., 2013), laterally correlative to pedogenized floodplain muds, whereas Holocene deposits are composed of predominant flood plain muds grading basinward into coastal and shallow marine facies associations. This is the case of the Po Plain, in northern Italy, where due to ongoing subsidence, 100 kyr depositional cycles may attain thickness of about 100 m (Amorosi et al., 2004). These depositional cycles have a typical glacial/interglacial signature, as revealed by the rhythmic alternation of laterally extensive channel belts formed under glacial conditions and floodplain dominated successions invariably associated with forest expansions (Amorosi et al., 2008b).

Vertical variations in the degree of interconnectedness and lateral extension of fluvial channel facies have also been used in pre Quaternary analogues to bracket depositional cycles composed of a basal, low accommodation systems tract (Olsen et al., 1995; Martinsen et al., 1999; Boyd et al., 2000; Zaitlin et al., 2002; Leckie et al., 2004; Ramaekers \& Catuneanu, 2004; Labourdette \& Jones, 2007; Hajek et al., 2010) or degradational (Currie, 1997), and an overlying, high accomodation or aggradational systems tract (Legarreta \& Uliana, 1998). Although transition from low to high sediment accumulation rates within each cycle is a widely accepted concept, changes in aggradation rates (ARs) have rarely been quantified. A recently published study on ancient fluvial systems, which investigated the variation in ARs over time periods of $10^{5}$ $10^{7}$ years (Colombera et al., 2015), argued that inferring low accommodation vs. high accommodation settings based on the degree of fluvial channel amalgamation is not substantiated by calculated ARs. As large intervals of time are likely related to highly discontinuous patterns of sedimentation, prolonged periods of nondeposition should be taken into account in the calculation of sedimentation rates (Sadler, 1981). Under this perspective, late Quaternary successions are best suited to this pur pose. The robust absolute chronology commonly associated with high resolution stratigraphic investigations of late Quaternary deposits (e.g. Fontana et al., 2008; Tanabe et $a l ., 2015)$ is ideal for identifying periods of nondeposition and for estimating their duration.

Several accumulation curves have been constructed for late Quaternary successions (Pandarinath et al., 2001; Tanabe et al., 2003; Molodkov \& Bitinas, 2006; Donnici et al., 2012; Zhang et al., 2012). Most studies on this subject, however, either have dealt with restricted areas/single cores (Lamoreaux et al., 2009; Tanabe et al., 2013; Leroy et al., 2014), or have focused on relatively short time periods (Wallinga et al., 2010).

A rapidly subsiding basin, such as the Po Basin (Carmi nati \& Di Donato, 1999; Carminati \& Martinelli, 2002), characterized by high sediment preservation potential, is an ideal site to estimate temporal variations in sediment accumulation. Like several late Quaternary successions from alluvial and coastal systems worldwide, the subsurface of the southern Po Plain is characterized by a striking contrast between Late Pleistocene and Holocene facies architecture. The general aim of this research is to verify if this abrupt change in stratigraphic architecture at the Pleistocene/Holocene transition was accompanied by a similar sharp change in ARs. Particularly, we intend to ascertain the extent to which low base level conditions can be responsible for low AR, even in continuously subsiding areas, such as the Po Plain. To this purpose, we calculated AR from 22 radiocarbon dated cores and we discussed the contribution of global and local factors to sediment accumulation. To unravel the role of base level variations on facies architecture and ARs, we compared our results from other coeval alluvial and coastal systems worldwide. For AR interpretation, we separated paleovalley systems from their adjacent interfluves. In order to establish changes in ARs as a function of increasing accommodation in different depositional settings, we focused on the Holocene stratigraphic succession of the southern Po Plain (Fig. 1), for which a conspicuous number of radiocarbon dates is available.

\section{Stratigraphic architecture of the Po Basin Fill}

The Po Plain is a foreland basin bounded by two mountain chains, the Southern Alps to the north and the Apennines to the south (Fig. 1a), showing opposite direction of tectonic transport. The external fronts of these two thrust belts are buried beneath the modern alluvial plain (Boccaletti et al., 2011). South of the Po River, the Po Basin appears as a wedge top basin fragmented by a series of north verging blind thrusts and folds (Fig. 1b). Some of these structures (e.g. Mirandola anticline) are tectonically active, as testified by the May 2012 seismic events (Anzi dei et al., 2012; Galli et al., 2012; Carannante et al., 2015). The stratigraphic succession consists of slightly deformed Pliocene deep marine units grading upsection into nearly undeformed Quaternary shallow marine and continental deposits (Ricci Lucchi, 1986). Due to high

subsidence rates (up to $2.5 \mathrm{~mm}$ year ${ }^{1}$ over the last 1.43 Ma; Carminati \& Di Donato, 1999), the Po Basin fill locally exceeds $8 \mathrm{~km}$ in thickness (Maesano et al., 2015). Long term subsidence is lower $\left(0.5-1.0 \mathrm{~mm}\right.$ year $\left.{ }^{1}\right)$ close to the buried anticlines, where the Plio Quaternary succession is just a few hundred metres thick.

The topmost portion of the Po Basin fill has been studied

in great detail over the last decades, based on facies analysis and stratigraphic correlation of core data. Stratigraphic studies from the modern coastal plain (Bondesan et al., 1995; Amorosi et al., 1999a, b, 2003, 2008a; Stefani \& Vincenzi, 2005; Dinelli et al., 2013) and from the Alpine (Fontana et al., 2014) and Apenninic (Amorosi et al., 2014) basin margins explored depositional cyclicity on a variety of time scales, from $10^{5}$ years (Amorosi et al., 2004, 2008b) to $10^{3}$ years (Amorosi et al., 2005, 2014; Scarponi et al., 2013). Comprehensive stratigraphic investigations of $c a .150 \mathrm{~m}$ long cores from the SE Po 


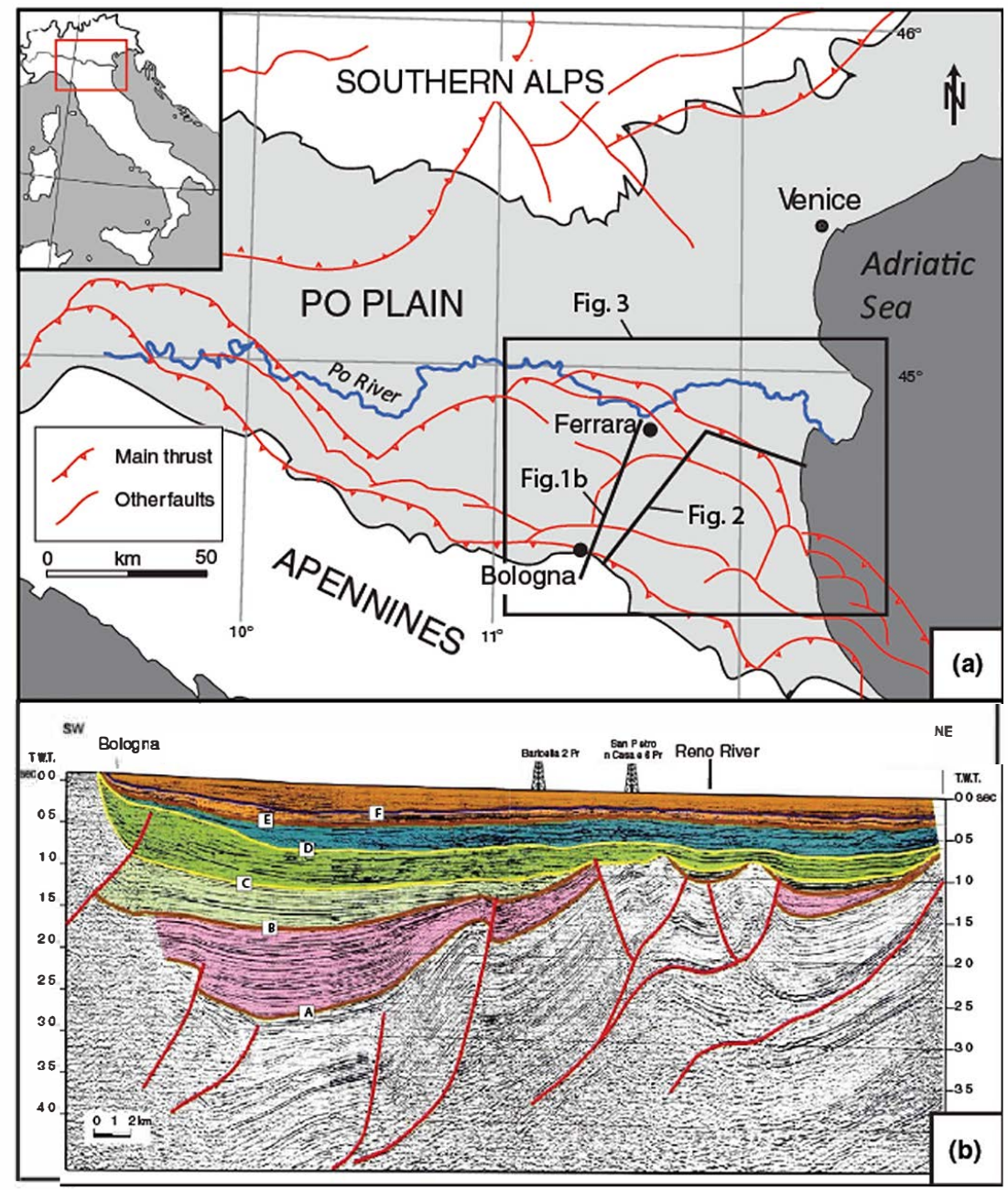

Fig. 1. (a) The Po Plain, with location of the seismic and stratigraphic profiles of Figs $1 \mathrm{~b}$ and 2 (modified from Burrato et al., 2003). (b) Int erpretation of a deep seismic profile transversal to the Apenninic margin (from Regione Emilia Romagna \& Eni Agip, 1998, location on Fig. la), with identification of the major blind thrusts (red lines), and the main stratigraphic unconformities (lines from A to $F$ ) within the Po Basin fill (coloured area).
Plain (Amorosi et al., 1999a, 2004) enabled identification of a cyclic alternation of alluvial sediments, mostly deposited during (lowstand) glacial periods, with coastal to shallow marine facies, reflecting sea level rise and highstand during the following interglacials. Particularly, two wedge shaped coastal and shallow marine bodies identified around $125-100 \mathrm{~m}$ and $<30 \mathrm{~m}$ depth were assigned to MIS 5e and the present interglacial (MIS 1), respectively on the basis of pollen curves and radiometric data. Alternating phases of sea level fall and rise between MIS $5 \mathrm{~d}$ and MIS 2 resulted in a $70 \mathrm{~m}$ thick succession of alluvial facies punctuated by subaerial unconformities and transgressive coastal deposits (Amorosi et al., 1999a). The most recent stratigraphic unconformity is associated with a characteristic paleosol formed in response to the Younger Dryas (YD) cold event (Amorosi et al., 1999b). 'This surface of subaerial exposure, locally named Caranto (Mozzi et al., 2003), has been detected throughout the northern Adriatic coastline. 'The Holocene transgressiveregressive wedge that unconformably overlies the YD paleosol (Irig. 2) is composed of two major units (Amorosi et al., 1999b, 2003): (i) a lower, thin succession of coastal plain and littoral facies, with distinctive retrogradational stacking pattern (transgressive systems tract); and (ii) an upper interval dominated by progradational (deltaic and strandplain) facies associations (highstand systems tract).
The maximum flooding surface (MISS) has been dated to about 7.5 cal ky BP.

At more proximal locations, the Po Basin fill consists entirely of nonmarine deposits. Close to the Apenninic chain and beneath the Po River, the alluvial facies are cyclically organized into laterally extensive channel belt sand bodies of glacial age alternating with mud dominated, interglacial successions (Amorosi et al., $2008 \mathrm{~b}$ ). On the interfluves, the fluvial channel belts are replaced by coeval, overconsolidated floodplain muds (Amorosi et al., 2014). Closely spaced, weakly developed paleosols brack eting time intervals of several thousand years, are interbedded with thin overbank strata (Amorosi et al., 2014). 'The youngest phase of soil development is dated to about 12.5-10 cal ky BP and coincides with the formation of the YD paleosol (Amorosi et al., 2014). 'These pedoge nized Late Pleistocene muds grade upsection into poorly drained Holocene floodplain deposits alternating with more immature and laterally discontinuous paleosols (I i ig. 2).

\section{METHODS}

'This work is based on the Regione Emilia Romagna stratigraphic database, which includes cores recovered as 
Fig. 2. Schematic cross section showing the depositional architecture of the (Lua ternary portion of the Po Basin fill (modi fied from Amorosi et al., 2014). I: Iolocene; P: Pleistocene; YD: Younger Dryas; MFS: maximum flooding surface. Location on Fig. 1.

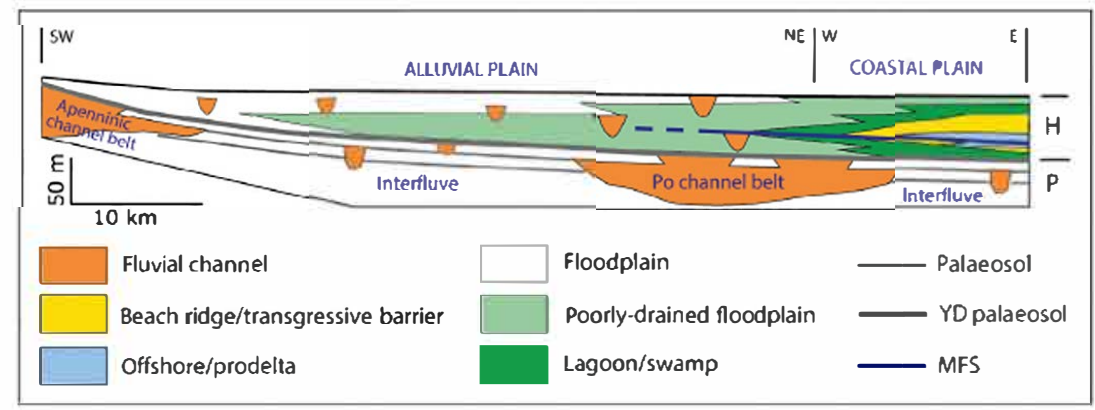

part of the Geological Mapping Project of Italy to scale $1: 50.000$. Additional stratigraphic data were derived from piezocone tests (CP'IL) and sedimentological descriptions of well cuttings. Cores and CP'IU were used for detailed facies characterization, with specific attention to the identification of paleosols. CP' ${ }^{\prime} U$ interpretation was based on Amorosi \& Marchi (1999). Well data, con- taining simple lithologic information (gravel, sand, clay), were used to define geometries and lateral extent of sedimentary bodies interpretable as channel deposits, after calibration with nearby core descriptions.

Radiocarbon dates from 22 selected cores (Fig. 3) and from previously published papers (Amorosi et al., 2005, 2008a, 2014, 2015; Scarponi et al., 2013) were used to cal culate sediment accumulation rates in the southern $P_{0}$

Plain during the last $40 \mathrm{ky}$. Conventional ${ }^{14} \mathrm{C}$ ages were calibrated using ()xCal 4.2 (Bronk Ramsey, 2009) with the IntCal 13 curve (Reimer et al., 2013). Aggradation rates between two radiocarbon dated samples were calculated taking into account the $l \sigma$ ranges, using the follow ing formula:

$$
\begin{gathered}
\mathrm{AR}_{\max }\left[\mathrm{mm} y \text { ear }{ }^{1}\right]=\Delta y[\mathrm{~m}] * 1000 /\left({ }^{\prime}{ }^{2} 2_{1 \sigma \max }\right. \\
\left.-{ }^{\prime} 1_{1 \sigma \min }\right)[y \text { ear }] \\
\mathrm{AR}_{\min }=\Delta y * 1000 /\left({ }^{\prime} \mathrm{I} 2_{1 \sigma \min }-\mathrm{T} 1_{1 \sigma \max }\right)
\end{gathered}
$$

where $\Delta y$ is the thickness of the stratigraphic interval between ages ' $\mathrm{T} 2$ and $\mathrm{T} 1$, with ' $\mathrm{T} 2>\mathrm{T} 1$.

Aggradation rates were represented through age/depth diagrams, into which the mean values between $A R_{\max }$ and $\mathrm{AR}_{\min }$ were depicted. Compaction effects were not taken into account (see discussion below). 'The chronologic framework for the Holocene succession was refined using archaeologically dated paleosols (Bruno et al., 2013) and

${ }^{14} \mathrm{C}$ c calibrated racemization dates (Scarponi et al., 2013).

For comparison, we also selected 10 sites from the existing literature for which detailed stratigraphic information and chronometric data based on ${ }^{1+} \mathrm{C}$ and optically stimulated luminescence were available. In order to obtain continuous sediment accumulation curves, we excluded uplifting areas, where Late Pleistocene and Holocene units crop out as terraced deposits, from our analysis.

\section{Late Quaternary aggradation rates from the southern Po Plain}

Based on Late Pleistocene stratigraphic architecture, the southern Po Basin can be subdivided into two main sectors (Fig. 3). Sector 1, extending for about $20 \mathrm{~km}$ south of the modern Po River, consists of aggradationally stacked channel belt sand bodies supplied by the Po River during
Fig. 3. Study area with location of the age depth diagrams of Figs 4 (red circles) and 6 (blue circles) and the stratigraphic logs of Figs 5 and 7 (black dots). 1: Boundary between the MIS 42 Po channel belt (sector 1) and the coeval interfluve (sector 2), 2: Adriatic shoreline during the Holocene maximum marine ingression (from Amorosi el al., 20008c), 3: culminations of the main buried thrust (modified after Boccaletti el al., 2011; 4: trace of the cross section of Fig. 5.

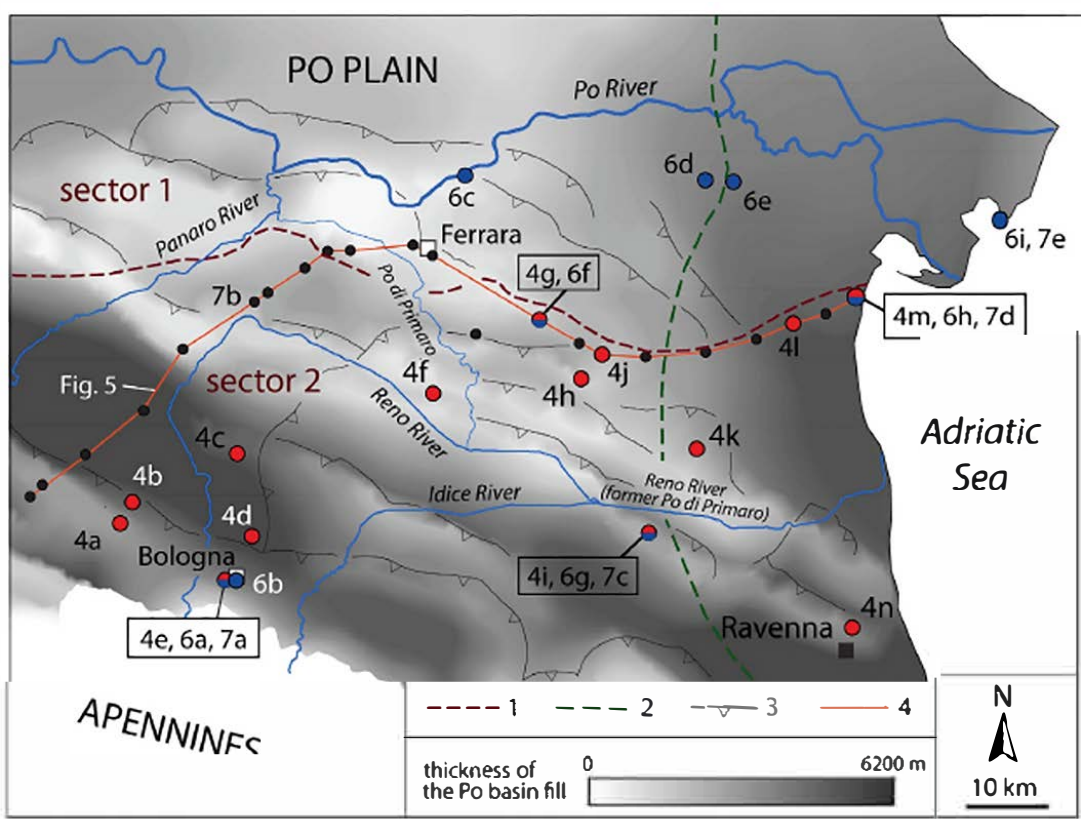


MIS 4 to MIS 2. Sector 2, between sector 1 and the Apen ninic margin, mostly acted as a wide interfluve during the last $40 \mathrm{ky}$. In this area, the mud prone Late Pleistocene succession includes thin floodplain units bounded by weakly developed paleosols, with minor fluvial bodies related to the Apenninic drainage (Amorosi et al., 2014). In order to investigate sediment accumulation trends during the last $40 \mathrm{ky}$, we selected 16 cores from sector 2, where the Pleistocene/Holocene boundary is marked by the YD paleosol. In the age/ depth diagrams of Fig. 4, we plotted the two most significant key stratigraphic surfaces (the YD paleosol and the MFS) to highlight the relationships between stratigraphic architecture and ARs.
Sediment accumulation patterns in sector 2 exhibit a common trend, characterized by a distinctive, sharp increase in ARs across the Pleistocene/Holocene bound ary (Fig. 4). In particular, the Pleistocene ARs are inv ariably $<0.9 \mathrm{~mm}$ year ${ }^{1}$, while mean Holocene values range between about 1 and $3 \mathrm{~mm}$ year ${ }^{1}$. Holocene aggradation was lowest $\left(<1.5 \mathrm{~mm}\right.$ year $\left.{ }^{1}\right)$ close to the Apenninic margin (4e in Figs 3 and 4 ) and in proximity of the buried thrust fronts, where the thickness of the basin fill is minimum ( $4 \mathrm{f}$ and $4 \mathrm{k}$ in Figs 3 and 4 ). In contrast, maximum Holocene aggradation $(2.4-2.9 \mathrm{~mm}$ year ${ }^{1}$ ) took place in the most distal sectors of the plain ( $41,4 \mathrm{~m}$ and $4 \mathrm{n}$ in Figs 3 and 4 ). 'The density of

\section{Age (cal ky BP)}
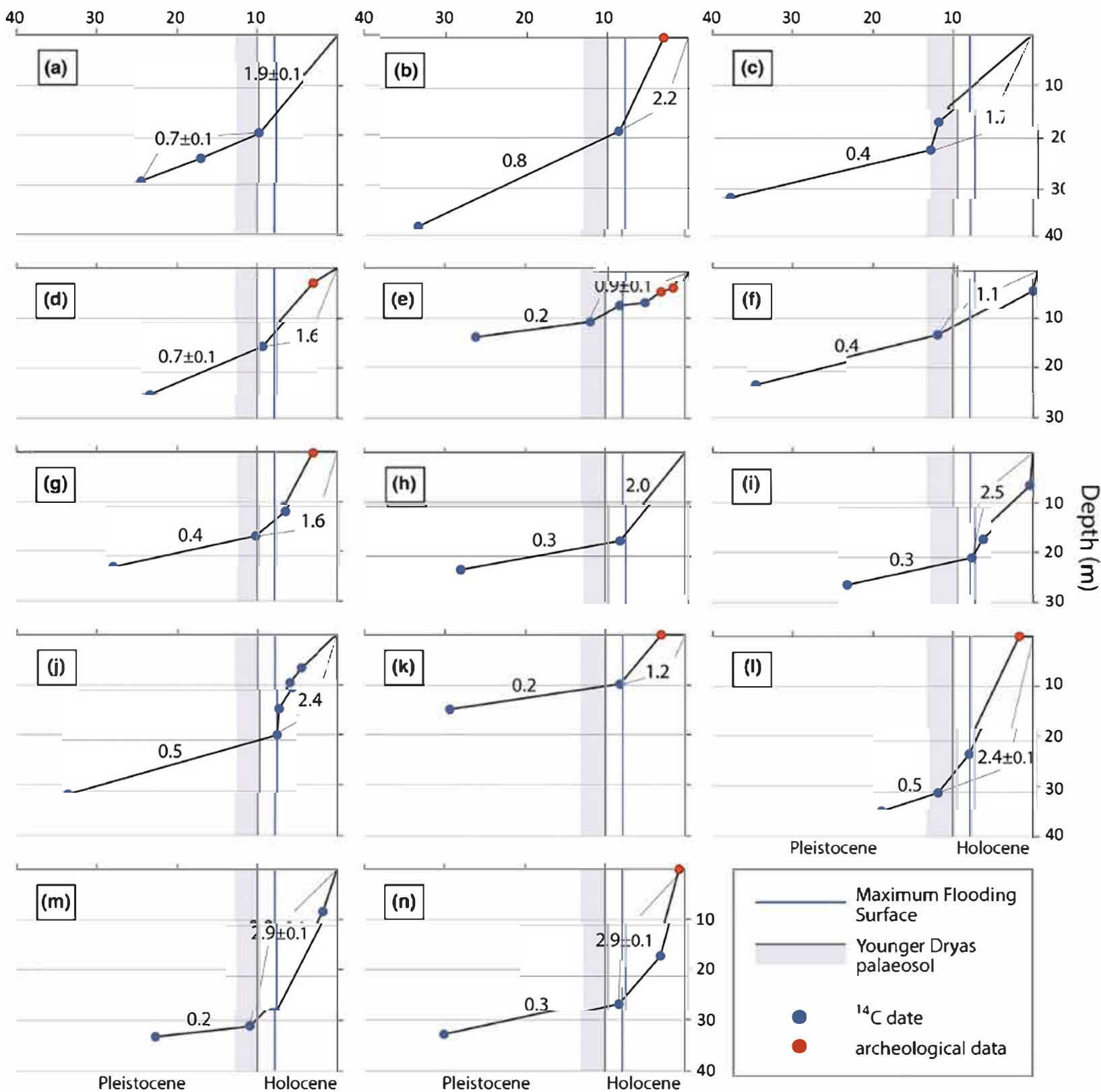

Fig. 4. Age depth diagrams based on radiocarbon dated cores (from sheets 203, 204, 205, 220, 221 and 223 of the Geological Map of Italy to scale $1: 50(00)$ ). Profile te is based on Amorosi et al. (2014). Location on Fig. 3. Error bars are not indicated, because smaller than the spots representing the mean aggradation rates (ARs). 
chronologic data along the individual cores is generally insufficient to locate precisely the point at which the gradient of the curve changes. Given the influence of the stratigraphic position of dated samples on sedimentation rate estimates, the measured ARs should be regarded as an approximation of the Pleistocene and Holocene ARs.

In general, significant changes in sediment accumulation rates are associated with the two surfaces that mark the major changes in stratigraphic architecture (Figs 4 and 5), i.e. the YD paleosol (Figs $4 a, c, d, e, f, g, 1, m$ ) and the MFS (Figs 4b, h, i, j, k, n). In contrast, no significant changes in ARs took place between about 30 and 10 cal ky $\mathrm{BP}$, an interval of time represented by a relatively thin $(<10 \mathrm{~m})$ sedimentary succession, with an abundance of pedogenized clays (Fig. 5).

On top of the YD palaeosol, progressively younger ages (between 9.7 and $5.2 \mathrm{cal} \mathrm{ky} \mathrm{BP}$ ) are recorded from distal to proximal locations (Fig. 5). Sediment accumulation profiles above the YD paleosol display no specific trends (Fig. (6), and extremely variable AR values, between 0.02 and $62 \mathrm{~mm}$ year ${ }^{1}$, are reconstructed from the Holocene succession. The comparison between sediment accumulation rates and the vertical stacking of facies (Fig. 7) shows that sedimentation rates varied significantly during the Holocene as a function of the different facies associations, the highest values being associated with late Holocene prodelta (up to $62 \mathrm{~mm}$ year ${ }^{1}$ ), beach ridge $\left(7-30 \mathrm{~mm}\right.$ year $\left.{ }^{1}\right)$, fluvial channel $\left(>20 \mathrm{~mm}\right.$ year ${ }^{1}$ ) and crevasse splay or channel $\left(5-20 \mathrm{~mm}\right.$ year $\left.{ }^{1}\right)$ cleposits (Figs 6 and 7). 'The lowest ARs are associated with flood

plain and paludal facies associations $\left(<3 \mathrm{~mm}\right.$ year $\left.{ }^{\mathrm{l}}\right)$, with very low values from pedogenized clays $\left(<1 \mathrm{~mm}\right.$ year $\left.{ }^{1}\right)$. In more distal positions, the lowest sed imentation rates $\left(<1.7 \mathrm{~mm}\right.$ year $\left.{ }^{1}\right)$ were measured in condensed offshore clays, close to the maximum flooding zone (Figs 7d, e).

\section{Changes in aggradation rates as a function of base-level fluctuations}

\section{Aggradation on the interfluves}

Facies analysis and radiocarbon dates from 16 interfluve records of the southern Po Plain reveal consistent relationships between late Qulaternary stratigraphy and ARs. The lowest ARs are observed in pedogenically modified muds dated at about 30-10 cal ky BP, and reflect deposition under low accommodation conditions (Wright \& Marriott, 1993; McCarthy et al., 1999; Boyd et al., 2000; Plint et al., 2001; Zaitlin et al., 2002). During the Last Glacial Maximum, between 30 and 18 cal ky BP, the Alpine glaciers expanded up to the valley outlets in the Po Plain (Fontana et al., 2014), feeding their related fluvioglacial systems. The Northern Apennines, on the contrary, were covered by few glaciers of limited extent, and vegetation was predominantly herbaceous (Amorosi et al., 1999b, 2004, 2008b; Vescovi et al., 2010). As the Apenninic catchments are largely composed of highly erodible rocks (Pini, 1999), the scarce vegetation cover strongly enhanced erosion and sediment delivery to the trunk rivers (Simoni et al., 2013). These concurrent circumstances ensured a conspicuous sediment input to the river systems. However, large part of this sediment by passed the Po Plain area, being delivered to the coeval coastline about $300 \mathrm{~km}$ seaward, at the northern edge of the Mid Adriatic depression (Correggiari et al., 1996; 'Trincardi \& Correggiari, 2000). 'The remaining portion accumulated in large channel belt bodies in the central Po Basin and at the Apenninic margin (Fig. 2). No significant aggradation is recorded on the adjacent Apenninic interfluve (sector 2, Fig. 3), where a series of vertically stacked paleosols developed south of the Po channel belt (see type 2 uncon formity on Wright \& Marriott, 1993). 'This implies that sedimentation was mostly restricted to low relief fluvial
Fig. 5. Stratigraphic cross section depicting contrasting facies architecture of Late Pleistocene vs Holocene deposits, along with gradients of the Younger Dryas (YD) palaeosol and of the modern topographic surface. Section trace on Fig. 3. Facies associations ( 17 ) include fluvial channel (1), floodplain (2), poorly drained floodplain (3), swamp (4), lagoon (5), transgressive barrier, beach ridge (6) and prodelta (7) deposits. Key strati graphic surfaces include the maximum flooding surface (8), the Y ounger Dryas paleosol (9) and older paleosols (10). (11) Radiocarbon dates (calibrated ky BP; asterisk indicates projected dates), (12) racemization dates (Scarponi $e t$ al., 2013).

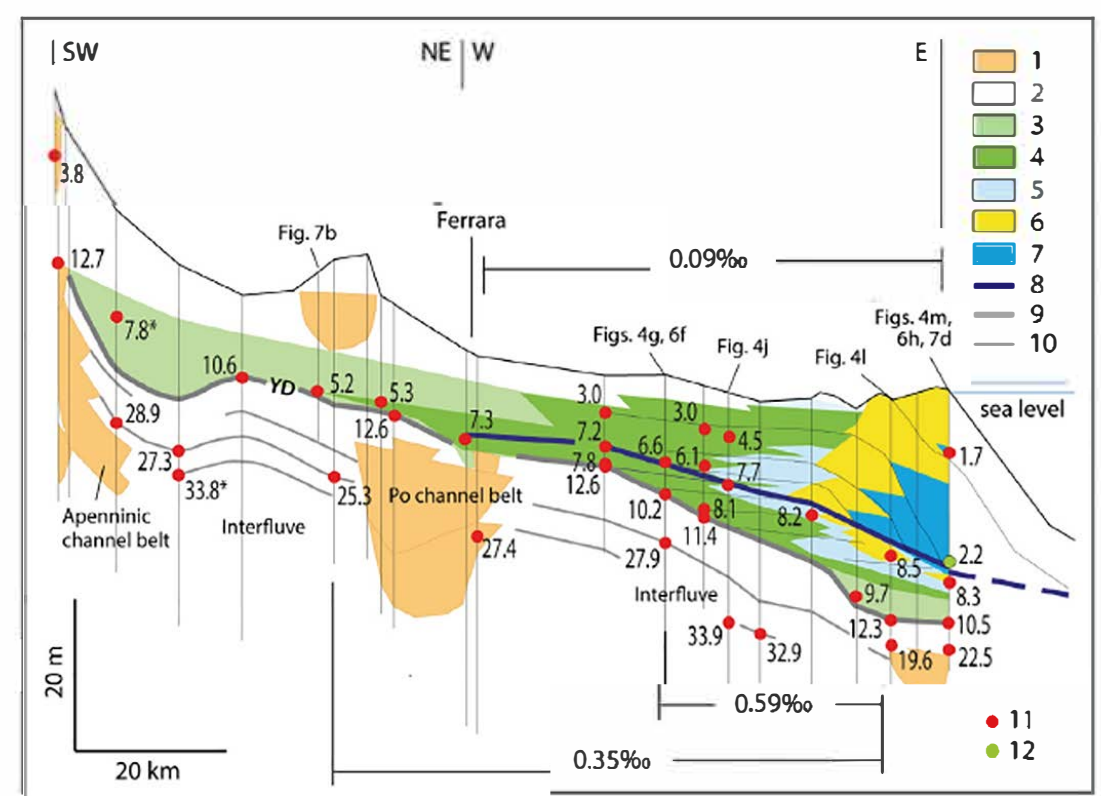



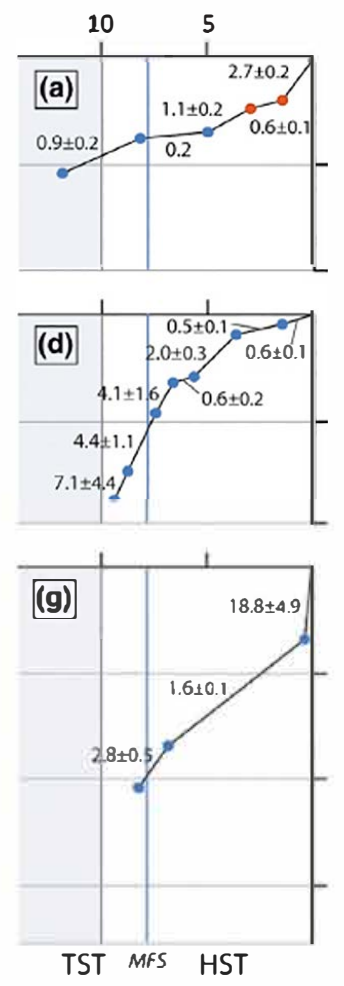
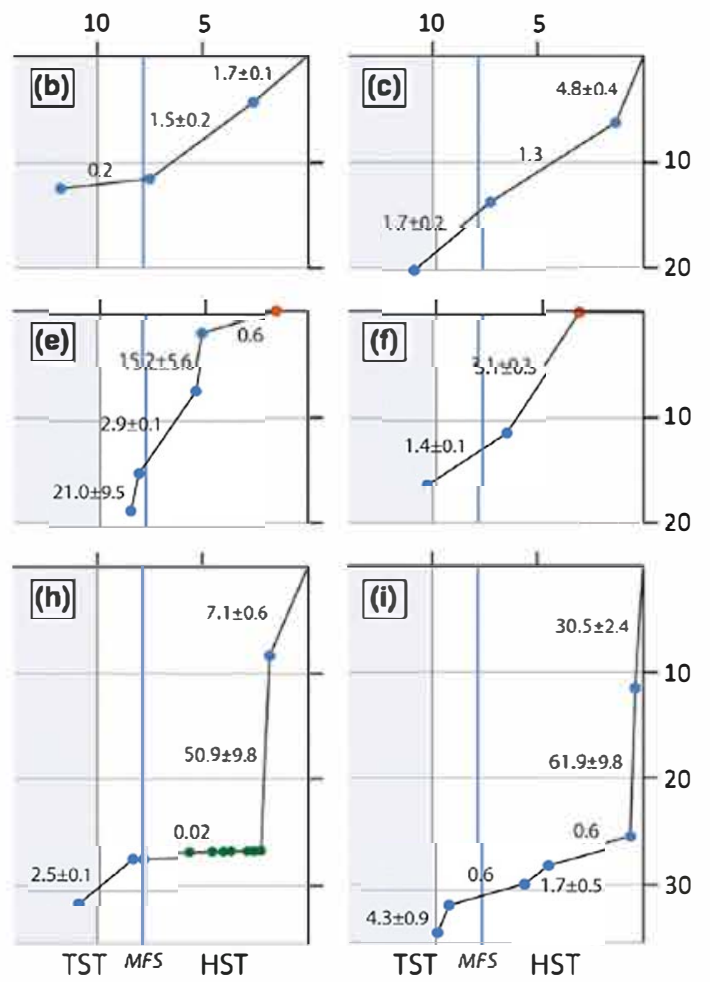

Fig. 6. Age depth diagrams focused on the last $13 \mathrm{ky}$, based on radiocarbon dated cores (from sheets 186, 187, 204 and 222 of the Geological Map of Italy to scale 1 : 50) (0)(0)). Profiles $6 \mathrm{a}$ and $6 \mathrm{~b}$ are based on Amorosi el al. (2014); 6h on Amorosi el al. (2003) and Scarponi el al. (2013); 6i on Amorosi el al. (2008a). Location on Fig. 3. Blue circle: ${ }^{14} \mathrm{C}$ age; red circle: age attribution based on archaeological evidence; green circle: age from amino acid racemization (Scarponi et al., 2013). The grey band on the left of each diagram represents the exposure time of the YD paleosol. TST: transgressive systems tra ct; HST: highstand sys tems tract; MFS: maximum flooding surface. Error bars are not indicated, because smaller than the spots represent ing the mean aggradation rates (ARs). incisions. 'Thin overbank layers between palaeosols (Fig. 5) testify to short lived phases of valley overfilling and floodplain aggradation that were possibly triggered by high frequency climate changes. 'Tectonic subsidence created space for sedimentation on the interfluves during lowstand.

Deglaciation, between 18 and 10 cal $\mathrm{ky} \mathrm{BP}$, did not lead to significant changes in ARs in sector 2. During this period, glacial lakes formed at the edge of the major Alpine valleys, acting as traps for large sediment volumes fed by northern sources. Moreover, as the Lateglacial coastal system was $250 \mathrm{~km}$ far away from the modern position (Storms et al., 2008), the study area was too far from its coeval coastline to be affected by marine transgression.

Around 10 cal ky 13P, the landward migrating shore line was about $50 \mathrm{~km} \mathrm{SE}$ of the modern Po delta (Correggiari et al., 1996; Storms et al., 2008). At that time, coastal swamps developed onto the YD paleosol in the most distal portion of the Po Plain (Fig. 7e; Amorosi et al., 1999b, 2003). 'The abrupt facies change from pedo genized alluvial deposits to organic rich clays marks the sharp increase in ARs (Fig. 4). The backstepping of bar rier lagoon systems induced by sea level rise is testified by the progressi vely younger ages of back barrier deposits covering the YD palaeosol at inland locations (Fig. 5). This tendency is observed only north of the buried Apen ninic front (Figs 3 and 5), and appears to be strongly influenced by the YD paleotopography. In particular, the youngest deposits overlying the YD paleosol are encoun tered above the buried anticlines, where the YD palaeosol has been uplifted (Figs 3 and 5). South of the buried anti- clines, scattered ages show that the burial of the YD palaeosol occurred before 8 cal ky $\mathrm{BP}$ (Figs 3, 5 and 7a).

'The backstepping of the barrier lagoon systems onto the YD palaeosol (Fig. 5) progressively reduced the gradient of the plain. After marine transgression and further progradation the gradient of the plain was reduced down from $0.35 \%$ (gradient of the $\mathrm{YD}$ paleosol in Fig. 5) to about $0.09 \%$ The landward migration of the coastline

also drastically reduced the area available for sediment storing. This evolution affected the equilibrium profile of the Po River, resulting in decreased stream power and downstream transport rates, and thus in decreased capability to erode banks and create space for lateral storage of bed load (Blum \& 'Törnqvist, 2000; Stouthamer \& Berendsen, 2007). As a consequence, the Po River started to aggrade, piling its sediments on the channel bed and on the interfluves through overflow, crevassing and avulsions (Correggiari et al., 2005). As the Po River represents a local base level for its tributaries, the Apenninic rivers aggraded in response to Po River aggradation.

Ihe latest Pleistocene-Holocene ARs from the Po Plain (Fig. 4) share significant similarities to sediment accumulation curves from coeval, alluvial and coastal systems worldwide, as revealed by the sediment accumula tion patterns of Fig. 8, which are summarized from the literature. Stratigraphic architecture at these sites shows the typical Late Pleistocene/Holocene bipartition of interfluvial areas: Late Pleistocene pedogenized floodplain deposits overlain by poorly drained floodplain or coastal facies. Considerable analogies between the shapes of the AR profiles of Figs 4 and 8 strongly suggest that the gen eralized increase in ARs at the Pleistocene/Holocene 


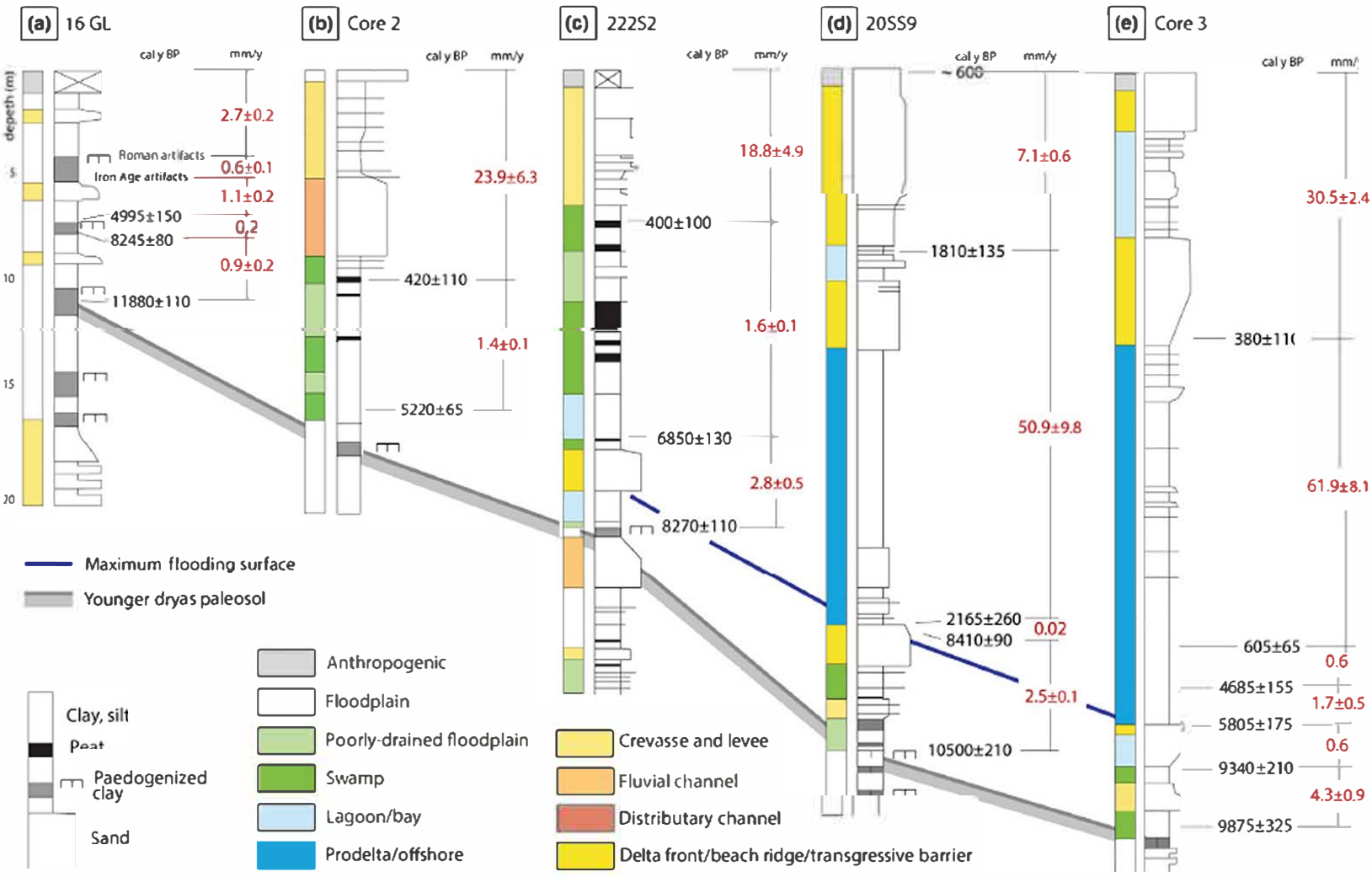

Fig. 7. Comparison between depositional facies and sedimentation rates in five cores from Amorosi et al. (2014)(a), Amorosi et al. (2015) (b), Sheet 222 of the Geological Map of Italy to scale $1: 50000$ (c), Scarponi et al. (2013)(d) and Amorosi et al. (200)8a) (e). Location on Fig. 3.

boundary was primarily controlled by allogenic factors (sea level rise). The interflu vial areas remained subaerially exposed (=low ARs) during the long phase of valley incision (sea level fall and lowstand) and during its filling (early transgression), with conseçuent paleosol develop ment (type 1 unconformity of Wright \& Marriott, 1993; interfluve sequence boundary of Mc(arthy \& Plint, 1998). Sedimentation started on the interfluves during the late stages of transgression (=high ARs), following complete valley filling (Posamentier et al., 1988; Van Wagoner et al., 1990; Foyle \& Oertel, 1997; Green, 2009; Weschenfelder et al., 2014).

\section{Aggradation rates in incised valley systems}

Contrary to the interfluves, no consistent trends and more variable shapes characterize AR profiles associated to incised valley fills, as a function of their relative position in the paleovalley (Fig. 9). At the margin of the paleovalleys (Fig. 9d, Aguzzi et al., 2007; Fig. 9f, Amorosi et al., 2013; Tyrrhenian coast of Italy), where buried fluvial terraces are commonly encountered, sediment accumulation rates rapidly increase at the boundary between fluvial ter raced deposits, exposed during further valley deepening, and overlying facies, deposited during later stages of transgression (about 12 cal ky BP, Fig. 10b). In these instances, low ARs associated to lowstand and early trans gressive deposits also reflect prolonged periods of nonde- position related to valley excavation. In contrast, AR profiles from areas close to the valley axis (Figs $9 \mathrm{~b}$ and 10c) show relatively homogeneous values for the last $20 \mathrm{ky}$, because sediment continuously accumulated since the early phases of marine transgression. An increase in $\mathrm{AR}$ at about $17 \mathrm{cal} \mathrm{ky} \mathrm{BP}$ is reconstructed from the age/ depth diagram of Figs $9 \mathrm{~b}$ and 10c (Echigo Plain, Japan, Tanabe et al., 2013), where numerical ages older than $30 \mathrm{ky}$ are available. In this deeply incised valley, the gen tle slope of the curve associated with the 35-17 ky time interval is interpreted to reflect removal of older sediment due to deepening of the valley, rather than nondeposition. In general, the onset of changes in ARs is progressively older from the interfluves to the valley axis (Fig. 10), as a function of the time transgressive filling of the valley.

\section{Autogenic control on accumulation rates}

Previous studies on Holocene sedimentary successions have attested to the strict relationship between sedimentation rates and sedimentary facies, in both fluvial and del taic settings (Hori et al., 2002; 'Törnqvist \& Bridge, 2002; Carvalho \& Schulte, 2013). Consistent with these works, we found that Holocene AR in the alluvial portion of the plain systematically decrease with increasing distance from the fluvial channel axis. Particularly, ARs associated to floodplain and swamp deposits are an order of magni tude lower than fluvial channel and channel related facies 

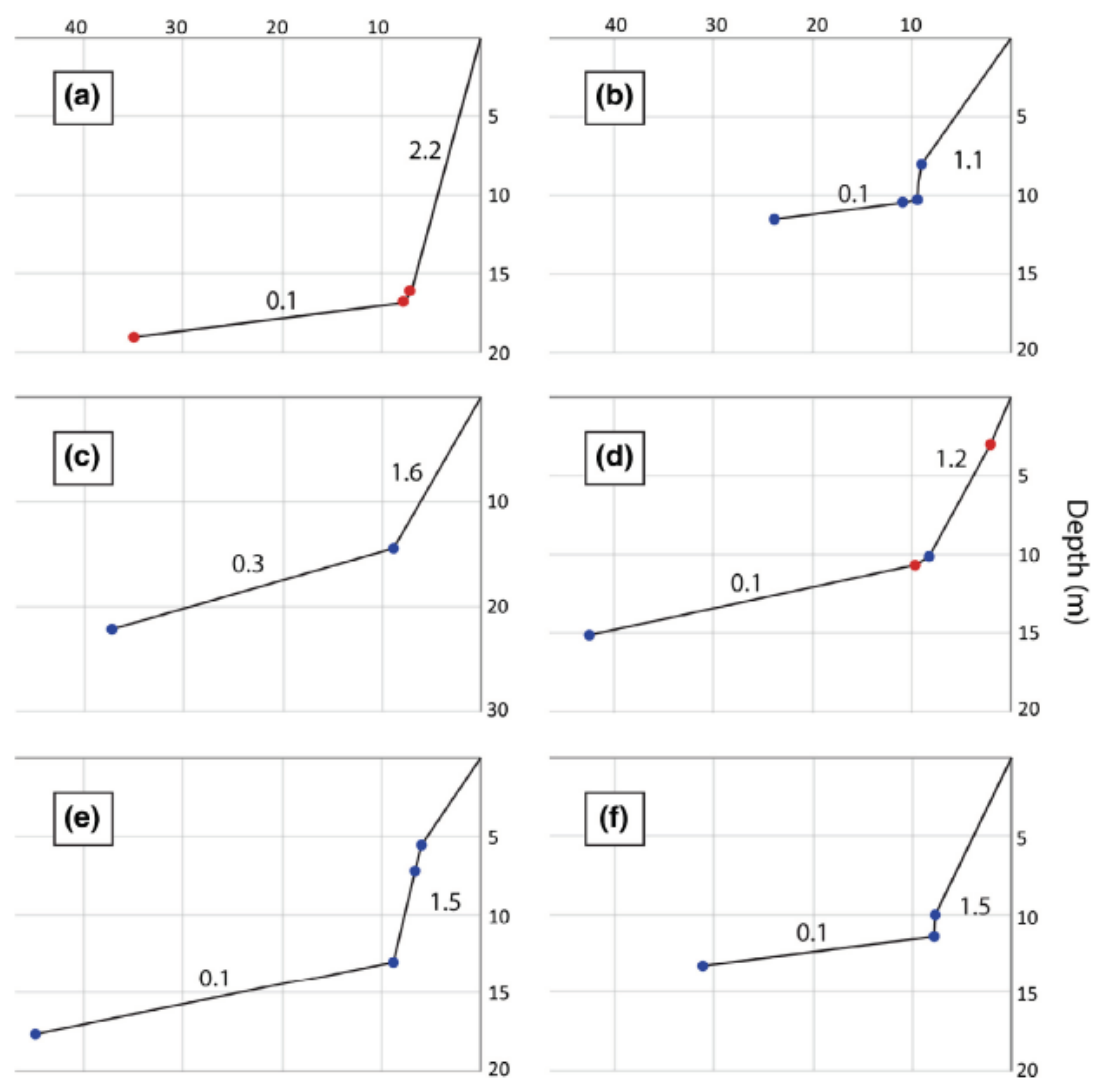

Fig. 8. Age depth diagrams, showing contrasting aggradation rates of Late Pleistocene and Holocene deposits, from radiocarbon dated cores. (a) Rhine Meuse system, The Netherlands (Buss chers et al., 2007); (b) Carmel coast, Israel (Sivan et al., 2011); (c) Volturno coastal plain, Italy (Amorosi et al., 2012); (d) South Bohai Sea, China (Yi et al., 2012); (e) West coast of Korea (Choi \& Kim, 2006); (f) Yeongsan Estuary, South West Korea (Nahm et al., 2008). Error bars are not indicated, because smaller than the spots representing the mean aggradation rates (ARs).

Age (cal ky BP)
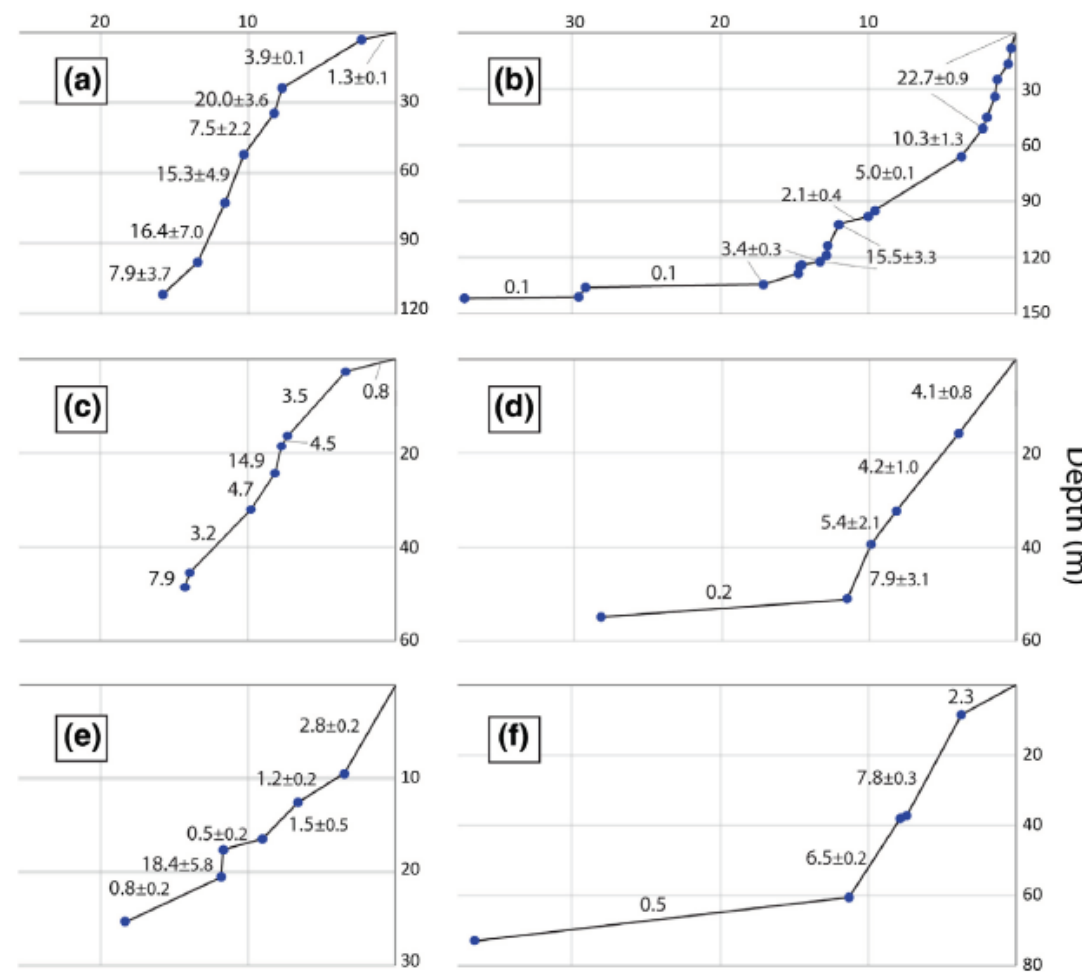

Fig. 9. Sediment accumulation patterns from incised valley fills. Age depth dia grams are from radiocarbon dated cores. (a) Columbia River estuary, Oregon, USA (Baker et al., 2010); (b) Echigo Plain, Japan (Tanabe et al., 2013); (c) Ganga delta plain, Bangladesh (Umitsu, 1993); (d) Arno Plain, Italy (Aguzzi et al., 2007); (e) Qiantag River estuary, China (Lin et al., 2005); (f) Stiava Plain, Italy (Amorosi et al., 2013). Error bars are not indicated, because smaller than the spots representing the mean aggradation rates (ARs).
(Fig. 7). In this respect, avulsions and crevassing appear to have played a key role in controlling local AR variations during the Holocene. An example is Core 2 in Fig. 7b
(Amorosi et al., 2015), where a sharp increase in ARs is recorded just above a 400 year old peat layer, which pre dates a historically documented avulsion of the Reno 
Fig. 10. Schematic representation of sediment accumulation patterns from incised valleys and related interfluves. Age depth diagrams are from: (a) Rhine Meuse system, The Netherlands (Buss cherset al., 2007), (b) Arno Plain, Italy (Aguzzi et al., 2007) and (c) Echigo Plain, Japan (Tanabe el al., 2013).

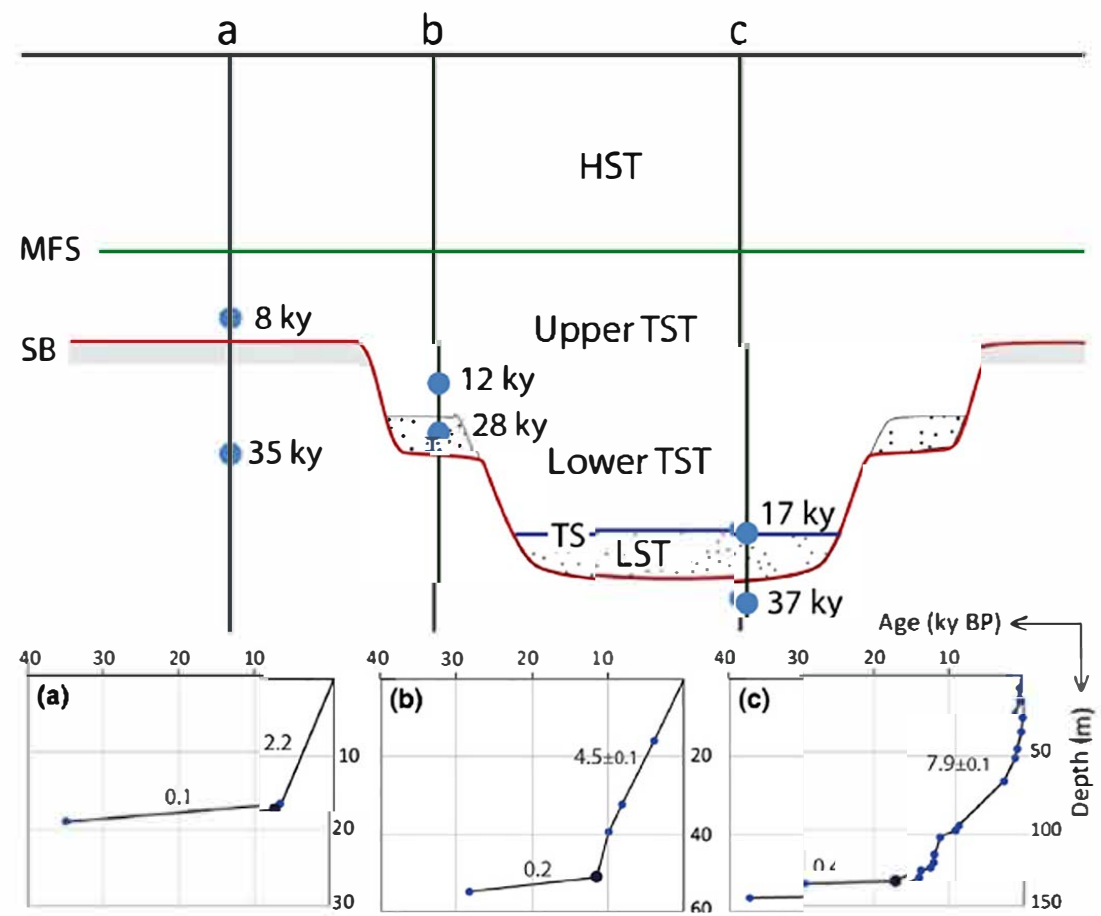

River in the 17th century. The importance of avulsions in supplying sediment to aggrading floodplains has been widely discussed (see Blum et al., 2013; for a review). The primary necessary condition in setting up the potential for avulsion is the decrease in the gradient of the alluvial plain (Stouthamer \& Berendsen, 2007), which is induced in this case by sea level rise and by the consequent landward shifting of the Po delta distributary system. Avulsions and crevasses are enhanced during periods of high sediment supply that may be promoted by rapid climate change (Leeder et al., 1998; Blum \& Törnqvist, 2000; Vandenberghe, 2003; Bruno et al., 2015). These processes, however, are either focused on specific sites (Aslan et al., 2005), such as pre existing topographic lows between consecutive fluvial ridges or can be generated by local subsidence. Avulsions are also favoured by channel ridge superelevation, which is a function of the local ratio between channel and floodplain ARs. In these instances, $\mathrm{AR}$ variations appear to be ultimately controlled by autogenic factors. Extremely low ARs, such as those measured on pedogenically modified floodplain clays, could reflect periods of climate induced low sediment supply, or elevated distance from a channel ridge.

The role of autogenic processes is increasingly dominant in the late Holocene succession of the Po Plain. Owing to increased accommodation with continuing relative sea level rise, late transgressive units were character ized by systematically higher ARs (>2 mm year ${ }^{1}$ ) than those associated with underlying, lowstand deposits (generally $<0.5 \mathrm{~mm}$ year ${ }^{1}$ ), consistent with a predominantly allogenic control. On the other hand, highstand sedimentation rates are highly variable, between almost 0 and $60 \mathrm{~mm}$ year ${ }^{1}$. This remarkable variability reflects the complex mechanisms of alluvial plain formation and coastal/ delta progradation. At time of maximum marine ingression, about 7.5 cal $\mathrm{ky} \mathrm{BP}$, the Adriatic coast was about $25 \mathrm{~km}$ inland of the present day shoreline (Amorosi et al., 2008c; Fig. 3). Radiocarbon dates from the most distal locations (Fig. 6h, i) testify to prolonged condensation around the time of maximum marine ingression (Scarponi et al., 2013), which preceded the onset of prograding delta lobes. At the base of thick prodelta mud successions, sedimentation rates rapidly switch from almost zero to $>50 \mathrm{~mm}$ year 1 . The sharp increase in sedimentation rates in core $205 \mathrm{~S} 9$ (Fig. $6 \mathrm{~h}$ and $7 \mathrm{~d}$ ), dated to about 2 cal $\mathrm{ky} \mathrm{BP}$, marks the activation of the $\mathrm{Po}_{\mathrm{o}}$ di Primaro deltal lobe (Stefani \& Vincenzi, 2005). The increase in sedimentation rates around 600 cal yr BP in Core 1 (Figs $6 \mathrm{i}$ and $7 \mathrm{e}$ ) reflects the onset of the modern Po delta, follow ing the Ficarolo avulsion (1152 AD), through which the Po River was shifted north, towards its present position (Amorosi et al., 2008a). In these contexts, changes in ARs measured on vertical profiles are largely controlled by patterns of delta progradation and delta lobe switching.

\section{Sediment compaction and the Sadler effect}

Through a set of 16 sediment accumulation profiles from the southern Po Plain, we demonstrate that sediment accumulation rates during the Late Pleistocene were invariably lower than mean Holocene ARs. However, inverse proportionality between $\mathrm{AR}$ and the age of the deposits could have been enhanced by compaction of older sediments or artificially induced by the Sadler effect (Sadler, 1981).

We consider the effects of sediment compaction negligible compared to the depth of our investigation $(40 \mathrm{~m})$ Specifically, pedogenically modified Late Pleistocene 
muds are poorly susceptible to post burial compaction. These sediments, subaerially exposed for thousands of years, are stiff and typically overconsolidated, as testified in CPTU tests by the high values of cone resistance and sleeve friction. In contrast, soft paludal, lagoonal and prodelta muds of Holocene age are strongly subject to postdepositional compaction (Massey et al., 2006; Törnqvist et al., 2008; Teatini et al., 2011). This implies that ARs calculated from Holocene deposits represent minimum values, and that the effect of sediment compaction may even lead to an underestimate of the contrast between Late Pleistocene and Holocene ARs.

Although the possible influence of the Sadler effect on the calculation of Late Pleistocene and Holocene ARs is generally minimized, because of the comparable length of time for the considered intervals, sediment accumulation curves built on low density radiocarbon dates can lead to unreliable interpretations, if not properly calibrated to a robust stratigraphic framework. In the case of the Po Plain, the YD paleosol plays a key role in influencing the accuracy of apparent sediment accumulation rates. While the formation of this palaeosol is almost synchronous across the study area (about 12.5 cal ky BP), its burial is highly diachronous, as documented by the characteristic onlapping geometry of the Holocene succession (Fig. 5). As a result, Holocene AR calculations based on radiocarbon dates from samples collected above the YD paleosol (Fig. 4b, h, i, j, k, n) might overestimate accumulation rates, simply because shorter amounts of time would be included in the calculation due to the local stratigraphic gaps. In contrast, no variation in apparent ARs would be recorded where dates from the YD palaeosol are available (Fig. 4a, c, e, f, g, 1, m). In this perspective, the use of well constrained, isochronous stratigraphic markers appears to be a fundamental tool in deciphering how ARs are distributed in space or may change over time.

\section{CONCLUSIONS}

Radiocarbon dates and facies analysis from 22 cores in the highly subsiding southern Po Basin revealed contrasting ARs as a function of late Quaternary facies architecture. The major conclusions that can be drawn from this study are as follows:

(1) Low AR (<0.9 mm year $\left.{ }^{1}\right)$ were reconstructed from Late Pleistocene pedogenically modified clays and associated floodplain deposits, whereas Holocene ARs exhibit invariably higher values (1-3 mm year ${ }^{1}$ ). The abrupt increase in ARs is observed close to the Late Pleistocene-Holocene boundary (YD palaeosol). Above this stratigraphic unconformity, the depositional architecture is characterized by widespread development of poorly drained floodplain and coastal facies associations.

(2) The contrast between Late Pleistocene and Holocene ARs appears to be controlled mostly by base level vari ations and by the consequent modifications in basin topography (i.e. gradient and extent of the area available for sedimentation). The most substantial changes in ARs and facies architecture are dated around $10 \mathrm{cal} \mathrm{ky} \mathrm{BP}$ (late stages of transgression), when landward migrating barrier lagoon systems were a few tens of kilometres off the modern shoreline, and wide coastal swamps developed in large parts the study area. The impact of other controlling factors on ARs, such as changes in the rates of sediment production and tecton- ics, appears to be subordinate or of local significance.

(3) The central role of late Quaternary base level variations in controlling sediment accumulation rates is substantiated by the comparison with data from the interfluves of other coeval, alluvial and coastal systems worldwide, where the transition from Late Pleistocene (lowstand) to Holocene (transgressive) facies architecture is associated with abruptly increasing ARs. Mark edly different AR profiles are observed in incised valley systems as a function of the mechanisms of valley for mation and filling. Particularly, increasing ARs at the base of transgressive deposits show progressively older ages moving from the interfluves to the valley axis.

(4) The significant spatial variability in Holocene ARs in the southern Po Plain suggests that, following maximum marine ingression, sediment accumulation pat terns were strongly influenced by autogenic processes, the highest sedimentation rates being recorded by delta progradation and fluvial channel aggradation.

This work highlights the strong potential of late Quaternary successions as ideal targets to assess the relationships between facies architecture and sediment accumulation patterns. A high resolution stratigraphic and chronologic control, with specific emphasis on quantification of major depositional hiatuses, is crucial for a correct interpretation of $\mathrm{AR}$ variations through time.

\section{ACKNOWLEDGEMENTS}

This study was supported by RFO grant 2013 from the University of Bologna to A. Amorosi. We gratefully thank Luca Colombera and an anonymous reviewer for their constructive suggestions. No conflict of interest declared.

\section{REFERENCES}

Aguzzi, M., Amorosi, A., Colalongo, M.L., Ricci Lucchi, M., Rossi, V., Sarti, G. \& Vaiani, S.C. (2007) Late Quaternary climatic evolution of the Arno coastal plain (Western Tuscany, Italy) from subsurface data. Sediment. Geol., 211, 211229.

Allen, G.P. \& Posamentier, H.W. (1993) Sequence stratigraphy and facies model of an incised valley fill: the Gironde Estuary, France. 7. Sediment. Petrolol., 63, 378391.

Amorosi, A. \& Marchi, N. (1999) High resolution sequence stratigraphy from piezocone tests: an example from the Late Quaternary deposits of the SE Po Plain. Sediment. Geol., 128, 6983. 
Amorosi, A., Colalongo, M.L., Fusco, F., Pasini, G. \& Fior INI, F. (1999a) Glacio eustatic control of continental shallow marine cyclicity from Late Quaternary deposits of the south eastern Po Plain (Northern Italy). Quatern. Res., 52, 113.

Amorosi, A., Colalongo, M.L., Pasini, G. \& Preti, D. (1999b) Sedimentary response to Late Quaternary sea level changes in the Romagna coastal plain (northern Italy). Sedimentology, 46, 99121.

Amorosi, A., Centineo, M.C., Colalongo, M.L., Pasini, G., Sarti, G. \& Vaiani, S.C. (2003) Facies architecture and Latest Pleistocene Holocene depositional history of the Po Delta (Comacchio area), Italy. 7. Geol., 111, 3956.

Amorosi, A., Colalongo, M.L., Fiorini, F., Fusco, F., Pasini, G., Vaiani, S.C. \& Sarti, G. (2004) Palaeogeographic and palaeoclimatic evolution of the Po Plain from $150 \mathrm{ky}$ core records. Glob. Planet. Change, 40, 5578.

Amorosi, A., Centineo, M.C., Colalongo, M.L. \& Fiorini, F. (2005) Millennial scale depositional cycles from the Holocene of the Po Plain, Italy. Mar. Geol., 222 223, 718.

Amorosi, A., Dinelli, E., Rossi, V., Vaiani, S.C. \& Sacchetto, M. (2008a) Late Quaternary palaeoenvironmental evolution of the Adriatic coastal plain and the onset of Po River Delta. Palaeogeogr. Palaeoclimatol. Palaeoecol., 268, 8090.

Amorosi, A., Pavesi, M., Ricci Lucchi, M., Sarti, G. \& Piccin, A. (2008b) Climatic signature of cyclic fluvial architecture from the Quaternary of the central Po Plain, Italy. Sediment. Geol., 209, 5868.

Amorosi, A., Fontana, A., Antonioli, F., Primon, S. \& Bonde SAN, A. (2008c) Post LGM sedimentation and Holocene shoreline evolution in the NW Adriatic coastal area. GeoActa, $7,4167$.

Amorosi, A., Pacifico, A., Rossi, V. \& Ruberti, D. (2012) Late Quaternary incision and deposition in an active volcanic setting: the Volturno valley fill, southern Italy. Sediment. Geol., 282, 307320 .

Amorosi, A., Rossi, V., Sarti, G. \& Mattei, R. (2013) Coales cent valley fills from the late Quaternary record of Tuscany (Italy). Quat. Int., 288, 129138.

Amorosi, A., Bruno, L., Rossi, V., Severi, P. \& Hajdas, I. (2014) Paleosol architecture of a late Quaternary basin margin sequence and its implications for high resolution, nonmarine sequence stratigraphy. Global Planet. Change, 112, 1225.

Amorosi, A., Bruno, L., Campo, B. \& Morelli, A. (2015) The value of pocket penetration tests for the high resolution palaeosol stratigraphy of late Quaternary deposits. Geol. 7., 50, 670682 .

Amos, C.L. \& Knoll, R.G. (1987) The Quaternary sediments of Banquereau, Scotian Shelf. Geol. Soc. Am. Bull., 99, 244 260.

Anzidei, M., Maramai, A. \& Montone, P. (2012) The Emilia (northern Italy) seismic sequence of May June, 2012: preliminary data and results. Ann. Geophys., 55, 515842 .

Aslan, A., Autin, W.J. \& Blum, M.D. (2005) Late Holocene avulsion history of the Lower Mississippi River, South Louisiana. 7. Sediment. Res., 75, 648662.

Autin, W.J., Burns, S.F., Miller, B.J., Saucier, R.T. \& SNEAD, J.I. (1991) Quaternary geology of the Lower Missis sippi Valley. In: Quaternary Non Glacial Geology: Contermi nous U.S. (Ed. by Morrison R.B.) Geological Society of America, The Geology of North America, K-2, 547582.

Baker, D., Peterson, C., Hemphill Haley, E. \& Twichell, D. (2010) Latest Pleistocene and Holocene (2 $16 \mathrm{ka}$ ) sedimenta tion in the Columbia River, Estuary, Oregon, USA. Mar. Geol., 273, 8395 .

Blum, M.D. \& Aslan, A. (2006) Signatures of climate vs. sea level change within incised valley fill successions: quaternary examples from the Texas Gulf Coast. Sediment. Geol., 190, 177211.

Blum, M.D. \& Tornqvist, T.E. (2000) Fluvial responses to climate and sea level change: a review and look forward. Sedimentology, 47, 248 .

Blum, M.D. \& Valastro, S. Jr (1994) Late Quaternary sedimentation, lower Colorado River, Gulf Coastal plain of Texas. Geol. Soc. Am. Bull., 106, 10021016.

Blum, M.D., Toomey, R.S. Iii \& Valastro, S. (1994) Fluvial response to Late Quaternary climatic and environmental change, Edwards Plateau, Texas. Palaeogeogr. Palaeoclimatol. Palaeoecol., 108, 121.

Blum, M.D., Martin, J., Milliken, K. \& Garvin, M. (2013) Paleovalley systems: insights from Quaternary analogs and experiments. Earth Sci. Rev., 116, 128169.

Boccaletti, M., Corti, G. \& Martelli, L. (2011) Recent and active tectonics of the external zone of the Northern Apennines (Italy). Int. F. Earth Sci., 100, 13311348.

Bondesan, M., Favero, V. \& Vinals, M.J. (1995) New evidence on the evolution of the Po delta coastal plain during the Holocene. Quat. Int., 29 30, 105110.

Boyd, R., Diessel, C.F.K., Wadsworth, J., Leckie, D. \& ZaiTLIN, B.A. (2000) Organization of non marine stratigraphy. In: Advances in the Study of the Sydney Basin, Proceedings of the 34th Nemcastle Symposium (Ed. by R. Boyd, C.F.K. Dies sel \& S. Francis), pp. 1 14. University of Newcastle, Cal laghan, NSW, Australia.

Bronk Ramsey, C. (2009) Dealing with outliers and offsets in radiocarbon dating. Radiocarbon, 51, 10231045.

Bruno, L., Amorosi, A., Curina, R., Severi, P. \& Bitelli, R. (2013) Human landscape interactions in the Bologna area (northern Italy) during the mid late Holocene, with focus on the Roman period. Holocene, 23, 15601571.

Bruno, L., Amorosi, A., Severi, P. \& Bartolomei, P. (2015) High frequency depositional cycles within the late Quaternary alluvial succession of Reno River (northern Italy). Ital. $\mathcal{F}$. Geosci., 134, 339354.

Burrato, P., Ciucci, F. \& Valensise, G. (2003) An inventory of river anomalies in the Po Plain, Northern Italy: evidence for active blind thrust faulting. Ann. Geophys., 44, 865882 .

Busschers, F.S., Weerts, H.J.T., Wallinga, J., Kasse, C., Cleveringa, P., De Wolf, H. \& Cohen, K.M. (2005) Sedimentary architecture and optical dating of Middle and Late Pleistocene Rhine Meuse deposits fluvial response to climate change, sea level fluctuation and glaciation. Neth. F. Geosci, 84,2541 .

Busschers, F.S., Kasse, C., Van Balen, R.T., Vanden berghe, J., Cohen, K.M., Weerts, H.J.T., Wallinga, J., Johns, C., Clevveringa, P. \& Bunnik, F.P.M. (2007) Late Pleistocene evolution of the Rhine Meuse system in the southern North Sea basin: imprints of climate change, sea level oscillation, and glacio isostacy. Quat. Sci. Rev., 26, 32163248 .

Carannante, S., Argnani, A., Massa, M., D’alema, E., Lovati, S., Moretti, M., Cattaneo, M. \& Augliera, P. (2015) The May 20 (MW 6.1) and 29 (MW 6.0), 2012, Emilia (Po Plain, northern Italy) earthquakes: new seismotectonic implications from subsurface geology and high quality hypocenter location. Tectonophysics, 655, 107123. 
Carminati, E. \& Di Donato, G. (1999) Separating natural and anthropogenic vertical movements in fast subsiding areas: the Po Plain (N. Italy) case. Geophys. Res. Lett., 26, 22912294.

Carminati, E. \& Martinelli, G. (2002) Subsidence rates in the Po Plain, northern Italy: the relative impact of natural and anthropogenic causation. Eng. Geol., 66, 241255.

Carvalho, F. \& Schulte, L. (2013) Morphological control on sedimentation rates and patterns of delta floodplains in the Swiss Alps. Geomorphology, 198, 163176.

Chen, Y., Liu, J.C.L., Shien, Y. \& Liu, T. (2004) Late Pleis tocene to Holocene environmental changes as recorded in the sulfur geochemistry of coastal plain sediments, southwestern Taiwan. 7. Asian Earth Sci., 24, 213224.

Chог, K. \& KIM, S. (2006) Late Quaternary evolution of macrotidal Kimpo tidal flat, Kyonggi Bay, west coast of Korea. Mar. Geol., 232, 1734.

Colombera, L., Mountney, N.P. \& McCaffrey, W.D. (2015) A meta study of relationships between fluvial channel body stacking pattern and aggradation rate: implications for sequence stratigraphy. Geology, 43/4, 283286.

Correggiari, A., Field, M. \& Trincardi, F. (1996) Late Qua ternary transgressive large dunes on the sediment starved Adriatic shelf. In: Geology of Siliciclastic Shelf Seas (Ed. by De Batist M. \& Jacobs P.) Geological Society of London Special Publications, 117, 155169.

Correggiari, A., Cattaneo, A. \& Trincardi, F. (2005) Depositional patterns in the Late Holocene Po delta system. In: Concepts, Models and Examples (Ed. by Bhattacharya J.P. \& Giosan L.) SEPM Special Publication, 83, 365392

CURRIE, B.S. (1997) Sequence stratigraphy of non marine Juras sic Cretaceous rocks, central Cordilleran foreland basin system. Geol. Soc. Am. Bull., 109, 12061222.

Dineldi, E., Ghosh, A., Rossi, V. \& Vaiani, S.C. (2013) Mul tiproxy reconstruction of Late Pleistocene Holocene environmental changes in coastal successions: microfossil and geochemical evidences from the Po Plain (Northern Italy). Stratigraphy, 9, 153167.

Donnici, S., Serandrei Barbero, R. \& Canali, G. (2012) Evi dence of climatic changes in the Venetian Coastal Plain (Northern Italy) during the last 40,000 years. Sediment. Geol., 281, 139150.

Dung, B.V., Stattegger, K., Thanh, N.T., Van Phach, P., Dung, T.T. \& Thong, B.X. (2014) Late Pleistocene Holocene seismic stratigraphy of Nha Trang shelf, central Vietnam. Mar. Pet. Geol., 58, 789800.

Fontana, A., Mozzi, P. \& Bondesan, A. (2008) Alluvial megafans in the Venetian Friulian plain (north eastern Italy): evidence of sedimentary and erosive phases during Late Pleistocene and Holocene. Quat. Int., 189, 7190.

Fontana, A., Mozzi, P. \& Marchetti, M. (2014) Alluvial fans and megafans along the southern side of the Alps. Sediment. Geol., 301, 150171.

Foyle, A.M. \& Oertel, G.F. (1997) Transgressive systems tract development and incised valley fills within a Quaternary estuary shelf system: Virginia inner shelf, USA. Mar. Geol., 137, 227249

Galli, P., Castenetto, S. \& Peronace, E. (2012) May 2012 Emilia earthquakes (Mw 6, Northern Italy): macroseismic effects distribution and seismotectonic implications. Alpine Mediterr. Quat., 2, 105123.

Green, A.N. (2009) Palaeo drainage, incised valley fills and transgressive systems tract sedimentation of the northern
KwaZulu Natal continental shelf, South Africa, SW Indian Ocean. Mar. Geol., 263, 4663.

Hajek, E.A., Heller, P.L. \& Sheets, B.A. (2010) Significance of channel belt clustering in alluvial basins. Geology, 38, 535 538.

Hori, K., Saito, Y., Zhao, Q. \& Wang, P. (2002) Evolution of the coastal depositional systems of the Changjiang (Yangtze) River in response to late Pleistocene Holocene sea level changes. 7. Sediment. Res., 72, 884897.

Labourdette, R. \& Jones, R.R. (2007) Characterization of fluvial architectural elements using a three dimensional outcrop data set: Escanilla braided system, South Central Pyrenees, Spain. Geosphere, 3, 422434.

Lamoreaux, H.K., Brook, G.A. \& Knox, J.A. (2009) Late Pleistocene and Holocene environments of the Southeastern United States from the stratigraphy and pollen content of a peat deposit on the Georgia Coastal Plain. Palaeogeogr. Palaeoclimatol. Palaeoecol., 280, 300312.

Leckie, D.A., Wallace Dudley, K.E., Vanbeselaere, N.A. \& James, D.P. (2004) Sedimentation in a low accommodation setting: nonmarine (Cretaceous) Mannville and marine (Jurassic) Ellis Groups, Manyberries Field, southeastern Alberta,. Am. Assoc. Petrol. Geol. Bull., 88, 13911418.

LeEder, M.R., Harris, T. \& Kirkby, M.J. (1998) Sediment sup ply and climate change: implications for basin stratigraphy. Basin Res., 10, 718.

Legarreta, L. \& Uliana, M.A. (1998) Anatomy of hinterland depositional sequences: upper Cretaceous fluvial strata, Neuquen Basin, West Central Argentina. In: Relative Role of Eustasy, Climate and Tectonism in Continental Rocks (Ed. by Shanley K.W.\& McCabe P.J.) SEPM Special Publication, 59, 8392.

Leroy, S.A.G., López Merino, L., Tudryn, A. \& Chalié, F. (2014) Late Pleistocene and Holocene palaeoenvironments in and around the middle Caspian basin as reconstructed from a deep sea core. Quat. Sci. Rev., 101, 91110.

Lin, C., Zhuo, H. \& Gao, S. (2005) Sedimentary facies and evolution in the Qiantang River incised valley, eastern China. Mar. Geol., 219, 235259.

Maesano, F.E., D'ambrogi, C., Burrato, P. \& Toscani, G. (2015) Slip rates of blind thrusts in slow deforming areas: examples from the Po Plain (Italy). Tectonophysics, 643, 825.

Martinsen, O.J., Ryseth, A., Helland Hansen, W., Flesche, H., Torkildsen, G. \& IDIL, S. (1999) Stratigraphic base level and fluvial architecture: Ericson Sandstone (Campanian), Rock Sorings Uplift, SW Wyoming, USA. Sedimentology, 46, 235259.

Massey, A.C., Paul, M.A., Gehrels, W.R. \& Charman, D.J. (2006) Autocompaction in Holocene coastal back barrier sediments from south Devon, southwest England, UK. Mar. Geol., 226, 225241.

McCarthy, P.J. \& Plint, A.G. (1998) Recognition of interfluve sequence boundaries: integrating paleopedology and sequence stratigraphy. Geology, 26, 387390.

McCarthy, P.J., Faccini, U.F. \& Plint, A.G. (1999) Evolution of an ancient coastal plain: palaeosols, interfluves and alluvial architecture in a sequence stratigraphic framework, Cenoma nian Dunvegan Formation, NE British Columbia, Canada. Sedimentology, 46, 861891.

Molodkov, A. \& Bitinas, A. (2006) Sedimentary record and luminescence chronology of the Lateglacial and Holocene aeolian sediments in Lithuania. Boreas, 35, 244254. 
Mozzi, P., Bini, C., Zilocchi, L., Becattini, R. \& Mariotti LIPPI, M. (2003) Stratigraphy, palaeopedology and palinology of late Pleistocene and Holocene deposits in the landward sector of the lagoon of Venice (Italy), in relation to caranto level. Il Quaternario, 16, 193210.

Nahm, W., Kim, J.C., Bong, P., Kim, J., Yang, D. \& Yu, K. (2008) Late Quaternary stratigraphy of the Yeongsan Estuary, Southwestern Korea. Quat. Int., 176 177, 1324.

Olsen, T., Steel, R., Hogseth, K., Skar, T. \& Roe, S.L. (1995) Sequential architecture in a fluvial succession: sequence stratigraphy in the Upper Cretaceous Mesaverde Group, Price Canyon, Utah. F. Sediment. Res., B65, 265280.

Pandarinath, K., Shankar, R. \& Yadava, M.G. (2001) Late Quaternary changes in sea level and sedimentation rate along the SW coast of India: evidence from radiocarbon dates. Curr. Sci., 81, 594600 .

PINI, G.A. (1999) Tectonosomes and olistostromes in the argille scagliose of the Northern Apennines, Italy. Geol. Soc. Am. Spec. Pap., 335, 170.

Plint, A.G., McCarthy, P.J. \& Faccini, U.F. (2001) Non marine sequence stratigraphy: updip expression of sequence boundaries and systems tracts in a high resolution framework, Cenomanian Dunvegan Formation, Alberta foreland basin, Canada. Am. Assoc. Pet. Geol. Bull., 85, 19672001.

Posamentier, H.W., Jervey, M.T. \& Vail, P.R. (1988) Eustatic controls on clastic deposition I conceptual framework. In: Sea Level Changes: An Integrated Approach (Ed. by Wilgus C.K., Hastings B.S., Kendall C.G.C., Posamentier H.W., Ross C.A. \& Van Wagoner J.C.) SEPM Special Publication, 42, 109124.

Ramaekers, P. \& Catuneanu, O. (2004) Development and sequences of the Athabasca Basin, Early Proterozoic, Saskatchewan and Alberta, Canada. In: The Precambrian Earth: Tempos and Events, Developments in Precambrian Geology, 12, (Ed. by P.G. Eriksson, W. Altermann, D. Nelson, W. Mueller \& O. Catuneanu), pp. 705 723. Elsevier Science Ltd., Ams terdam.

Regione Emilia Romagna \& ENI AGIP (1998) Riserve idriche sotterranee della Regione Emilia Romagna. S.EL.CA., Firenze.

Reimer, P.J., Bard, E., Bayliss, A., Beck, J.W., Blackwell, P.G., Bronk Ramsey, C., Buck, C.E., Cheng, H., Edwards, R.L., Friedrich, M., Grootes, P.M., Guilderson, T.P., Haflidason, H., Hajdas, I., Hatte, C., Heaton, T.J., Hoffmann, D.L., Hogg, A.G., Hughen, K.A., Kaiser, K.F., Kro mer, B., Manning, S.W., Niu, M., Reimer, R.W., Richards, D.A., Scott, E.A., Southon, J.R., Staff, R.A., Turney, C.S.M. \& Van Der Plicht, J. (2013) IntCal13 and Marine13 radiocarbon age calibration curves, 0 50,000 years cal BP. Radiocarbon, 55/4, 18691887.

RICCI LuCCHI, F. (1986) Oligocene to recent foreland basins of northern Apennines. In: Foreland Basins (Ed. by Allen P. \& Homewood P.) International Association of Sedimentologists Special Publication, 8, 105 139. Blackwell Scientific, London.

SADLER, P.M. (1981) Sediment accumulation rates and the completeness of stratigraphic sections. F. Geol., 89, 569584.

Sarkar, A., Sengupta, S., McArthur, J.M., Ravenscroft, P., Bera, M.K., Bhushan, R., Samanta, A. \& Agrawal, S. (2009) Evolution of Ganges Brahmaputra western delta plain: clues from sedimentology and carbon isotopes. Quat. Sci. Rev., 28, 25642581.

Scarponi, D., Kaufman, D., Amorosi, A. \& Kowalewski, M. (2013) Sequence stratigraphy and the resolution of the fossil record. Geology, 41/2, 239242.
Simoni, A., Ponza, A., Picotti, V., Berti, M. \& Dinelli, E. (2013) Earthflow sediment production and Holocene sediment record in a large Apennine catchment. Geomorphology, $188,4253$.

Sivan, D., Greenbaum, N., Cohen Seffer, R., Sisma Ventura, G. \& Almogi Labin, A. (2011) The origin and disappearance of the Late Pleistocene Early Holocene short lived coastal wetlands along the Carmel coast, Israel. Quat. Res., 76, 8392.

Stefani, M. \& Vincenzi, S. (2005) The interplay of eustasy, climate and human activity in the late Quaternary depositional evolution and sedimentary architecture of the Po Delta sys tem. Mar. Geol., 222 223, 1948.

Storms, J.E.A., Weltje, G.J., Terra, G.J., Cattaneo, A. \& Trincardi, F. (2008) Coastal dynamics under conditions of rapid sea level rise: late Pleistocene to Early Holocene evolution of barrier lagoon systems on the northern Adriatic shelf (Italy). Quat. Sci. Rev., 27, 11071123.

Stouthamer, E. \& Berendsen, H.J.A. (2007) Avulsion: the relative roles of autogenic and allogenic processes. Sediment. Geol., 198, 309325.

Tanabe, S., Hori, K., Saito, Y., Haruyama, S., Vu, V.P. \& Kitamura, A. (2003) Song Hong (Red River) delta evolution related to millennium scale Holocene sea level changes. Quat. Sci. Rev., 22, 23452361.

Tanabe, S., Nakanishi, T., Matsushima, H. \& Hong, W. (2013) Sediment accumulation patterns in a tectonically subsiding incised valley: insight from the Echigo Plain, central Japan. Mar. Geol., 336, 3343.

Tanabe, S., Nakanishi, T., Ishihara, Y. \& Nakashima, R. (2015) Millennial scale stratigraphy of a tide dominated incised valley during the last $14 \mathrm{kyr}$ : spatial and quantitative reconstruction in the Tokyo Lowland, central Japan. Sedimen tology. doi:10.1111/sed.12204.

Teatini, P., Tosi, L. \& Strozzi, T. (2011) Quantitative evidence that compaction of Holocene sediments drives the present land subsidence of the Po Delta, Italy. 7. Geophys. Res., 116, B08407.

Tornqvist, T.E. \& Bridge, J.S. (2002) Spatial variation of over bank aggradation rate and its influence on avulsion frequency. Sedimentology, 49, 891905.

Tornqvist, T.E., Wallace, D.J., Storms, J.E.A., Wallinga, J., Van Dam, R.L., Blaauw, M., Derksen, M.S., Klerks, C.J.W., Meijneken, C. \& Snijders, E.M.A. (2008) Missis sippi Delta subsidence primarily caused by compaction of Holocene strata. Nat. Geosci., 1, 173176.

Trincardi, F. \& Correggiari, A. (2000) Quaternary forced regression deposits in the Adriatic basin and the record of composite sea level cycles. In: Sedimentary Response to Forced Regressions (Ed. by Hunt D. \& Gawthorpe R.L.) Geological Society of London Special Publication, 172, 245269.

Umitsu, M. (1993) Late Quaternary sedimentary environments and landforms in the Ganges delta. Sediment. Geol., 83, 177 186.

Van Wagoner, J.C., Mitchum, R.M., Campion, K.M. \& Rah MANIAN, V.D. (1990) Siliciclastic sequence stratigraphy in well logs, cores and outcrops: concepts for high resolution correlations of time and facies. American Association of Ameri can Petroleum Geologists, Methods in Exploration, 7, Barbara H. Lidtz, Tulsa, USA, 55pp.

Vandenberghe, J. (2003) Climate forcing of fluvial system development: an evolution of ideas. Quat. Sci. Rev., 22, 2053 2060. 
Vescovi, E., Kaltenrieder, P. \& Tinner, W. (2010) Late Glacial and Holocene vegetation history of Pavullo nel Frignano (Northern Apennines, Italy). Rev. Palaeobot. Palynol., 160, 3245.

VIs, G.J. \& KASSE, C. (2009) Late Quaternary valley fill succession of the Lower Tagus Valley, Portugal. Sedimet. Geol., 221, 1939.

Wallinga, J., Нobo, N., Cunningham, A.C., Versendaal, A.J., Makaske, B. \& Middelkoop, H. (2010) Sedimentation rates on embanked floodplains determined through quartz optical dating. Quat. Geochronol., 5, 170175.

Weschenfelder, J., Baitelli, R., Corrêa, I.C.S., Bortolin, E.C. $\&$ Dos Santos, C.B. (2014) Quaternary incised valleys in south ern Brazil coastal zone. 7. South Am. Earth Sci, 55, 8393.

Wright, V.P. \& MarriotT, S.B. (1993) The sequence stratigraphy of fluvial depositional systems: the role of floodplain sediment storage. Sediment. Geol., 86, 203210.

Yi, L., Yu, H.J., Ortiz, J.D., Xu, X.Y., Chen, S.L., Ge, J.Y., Hao, Q.Z., Yao, J., Shi, X.F. \& Peng, S.Z. (2012) Late Quaternary linkage of sedimentary records to three astronomical rhythms and the Asian monsoon, inferred from a coastal bore hole in the south Bohai Sea China. Palaeogeogr. Palaeoclima tol. Palaeoecol., 329 330, 101117.
Yoo, D.G., Kim, S.P., Chang, T.S., Kong, G.S., Kang, N.K., KwON, Y.K., NAM, S.L. \& PARK, S.C. (2014) Late Quaternary inner shelf deposits in response to late Pleistocene Holocene sea level changes: Nakdong River, SE Korea. Quat. Int., 344, 156169

Zaitlin, B.A., Dalrymple, R.W. \& Boyd, R. (1994) The stratigraphic organization of incised valley systems associated with relative sea level change. In: Incised Valley Systems: Origin and Sedimentary Sequences (Ed. by Dalrymple R.W., Boyd R. \& Zaitlin B.A.) SEPM, Special Publication, 51, 4560.

Zaitlin, B.A., Warren, M.J., Роtocki, D., Rosenthal, L. \& Boyd, R. (2002) Depositional styles in a low accommodation foreland setting: an example from the Basal Quartz (Lower Cretaceous), southern Alberta. Bull. Can. Pet. Geol., 50, 31 72.

Zhang, J., Liu, C., Wu, X., Liu, K. \& Zhou, L. (2012) Optically stimulated luminescence and radiocarbon dating of sediments from Lop Nur (Lop Nor), China. Quat. Geochronol., 10, 150 155. 